\title{
Candidates for ALA president share their plans
}

\author{
By Michael Gorman and Mary R. Somerville
}

Be sure to vote this spring

$\mathbf{T}$ he ALA Presidential Candidates' Forum at the 1995 Midwinter Meeting in Philadelphia encouraged lively discussion and CERL News asked each candidate to select one or more of the issues that came up and discuss for our readers how they will address them if elected president of ALA.

\section{MICHAEL GORMAN Technology}

Libraries have always been good at incorporating new forms of communication into their collections and services. I am confident that electronic communication will be no exception. I foresee libraries of the future in which information (data and short discrete packets of information) is held, transmitted, and used electronically, and knowledge is stored and acquired by use of print and other "traditional" forms enhanced by electronic resources. We need to be inclusive in creating a "virtual library service" as an important part of overall library service not "virtual libraries" as vastly inferior replacements for real libraries. ALA must support and foster a humane and service-oriented "whole library" concept.

\section{Literacy}

One of the most pressing issues in modern society is the rising tide of illiteracy, aliteracy, and subliteracy. Librarians should be spearheading efforts to resist these evils and to promote reading and lifelong literacy as the basis of

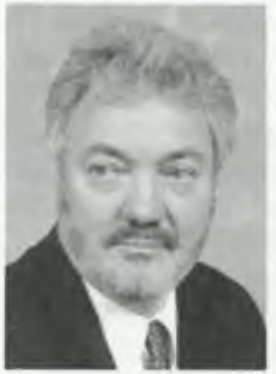

Michael Gorman

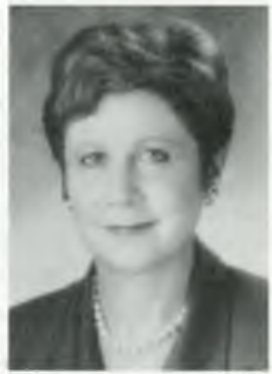

Mary R. Somerville personal empowerment. The alternative is a permanent, ever-expanding underclass of people who cannot read, write, or express themselves with clarity, and will never realize their gifts or fulfill their dreams. No librarian and no library should stand aside from this issue. The bitter experience of the California Great Tax Revolt is that the children who are neglected because of the starvation of their schools, school libraries, and public libraries become the young men and women who cannot or will not read and who lack all library skills when they enter colleges and universities. Academic, public, and

\section{ALA must look outward and lead the fight for libraries and the importance of what librarions do.}

school librarians should find common cause in the reality of the common plight of their users. What good is the freedom to read to people who cannot read? ALA must rally all librarians in the cause of literacy and reading. 


\section{Substance not process}

It seems that, in recent years, the association has become more process oriented and less focused on the substance of real world library issues. ALA needs leadership that will concentrate on practical problems, the reality of library life and work today, and the issues that concern its members. AlA needs an eloquent and passionate voice that will speak truth to power and represent libraries and librarians of all kinds at all levels of government and society. ALA must look outward and lead the fight for libraries and the importance of what librarians do.

\section{Power through unity}

It is essential that librarians come together over the values and issues that are important to usliteracy, adequate funding, service to humanity, intellectual freedom, preserving the records of civilization, the intelligent use of technology. It is also important that a united profession work with other agencies and individuals who share our values and our purpose. ALA must take the lead in uniting the profession and working with a broad range of cultural and educational bodies.

\section{MARY R. SOMERVILLE}

I accepted the nomination for the ALA presidency becaluse I believe we must lift every voice in collective advocacy. We owe it to ourselves. We owe it to library workers. Most importantly, we owe it to the public that relies on libraries as a sure foundation for intellectual participation. It's time we countered the earthquake quality to the climate of library support-to shout out that libraries and librarians are a critical part of the solution to the problems facing America, and that academic libraries are key to the research and education fueling America's intellectual and economic future.

\section{I believe we must lift every voice in collective advocacy. We owe it to ourselves.}

When ALA speaks, people listen. Now more than ever the agenda must be set so that we can speak consistently and effectively to ensure the critical role librarians can and must play in the electronic arena. As ALA President my goal is to ensure that our members and supporters are well trained, equipped, and mo- tivated to tell the library story. Electronic lobbying, fundraising, media campaigns, and the building of a citizen's network to advocate for all types of libraries are essential.

The agenda is clear:

- to stop the slow starvation of our libraries and library schools;

- to ensure that there are no more closings;

- to connect every library to the information highway and ensure equal, ready, and equitable access;

- to fight mounting censorship challenges;

- to allocate more resources for national, state, and local legislative efforts;

- to provide legislative advocacy and intellectual freedom support for youth services;

- to train and mentor young leaders to ensure the future of the profession;

- to achieve a cliverse library workforce for our multicultural users.

ALA's Goal 2000 is right on target and ACRL has demonstrated leadership in contributing $\$ 100,000$ toward that goal, which will expand the Washington Office and establish the Office for Information Technology Policy. As a member of the ALA Executive Board, I endorsed Goal 2000 early on, and promise to help ALA stay the course.

I'm ready to take up the challenge. Having dealt with the army and the Red Cross cluring the aftermath of Hurricane Andrew, not to mention downed power lines, missing roofs, many staff left homeless and unreachable, I'm experienced in crisis management, decisionmaking, and negotiation under fire-qualities that will be needed by the ALA President.

I know how to get things done, having activated two automated systems, now creating a microlibrary and an Internet project, and working with college and university libraries to bring up the SEFLIN FreeNet with an international emphasis.

As the first woman director to head one of the nation's ten largest public libraries, I lead 575 employees, manage a $\$ 35$ million budget and 31 facilities in an international, multicultural, multilingual community. I accepted the nomination for the ALA Presidency because I know I'll make a difference.

I ask for your vote because as your president I will focus ALA on an action agenda. Working with you-57,000 members strong-I know that together our advocacy can and will make a difference. 